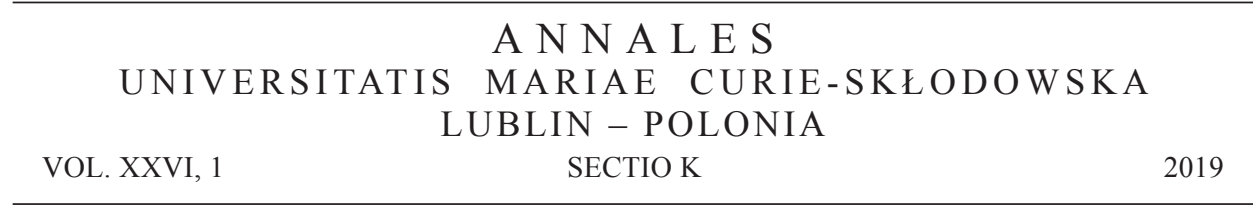

Uniwersytet Szczeciński. Instytut Politologii i Europeistyki

KRZYSZTOF KOWALCZYK

ORCID ID: ORCID 0000-0002-5910-4854

\title{
Wpływ prokościelnych grup interesu na ustawodawstwo. Casus regulacji antyaborcyjnych $w$ Sejmie VIII kadencji
}

The Influence of Pro-Church Interest Groups on Legislation.

Casus of Anti-Abortion Regulation in the Sejm of the $8^{\text {th }}$ Term

\begin{abstract}
ABSTRAKT
Zasadniczym celem artykułu jest omówienie wpływu prokościelnych grup interesu na proces stanowienia ustawodawstwa antyaborcyjnego w Polsce. Tekst odnosi się do inicjatyw podjętych w Sejmie VIII kadencji. Zanalizowano: rolę Kościoła katolickiego w systemie politycznym Polski; metody jego oddziaływania na ów system; pojęcie prokościelnych grup interesu; ich typologię; projekty ustaw dotyczących aborcji w Sejmie VIII kadencji; metody, jakimi grupy pro-life wyrażały swoje postulaty w trakcie prób stanowienia ustawodawstwa antyaborcyjnego. Grupy te są instrumentem wpływu Kościoła na system polityczny. W celu wprowadzenia ustawodawstwa antyaborcyjnego grupy obrońców życia odwołują się do różnych metod: lobbingu, zabiegów perswazyjnych i sankcji moralnych.
\end{abstract}

Słowa kluczowe: Kościół katolicki, Polska, grupy pro-life

\section{WSTĘP}

Celem artykułu jest omówienie wpływu prokościelnych grup interesu na proces stanowienia ustawodawstwa antyaborcyjnego w Polsce na przykładzie inicjatyw podjętych w Sejmie VIII kadencji (od 2015) ${ }^{1}$. Grupy te, funkcjonując w otoczeniu systemu politycznego, działają za zgodą Kościoła rzymskokatolickiego i/lub z in-

\footnotetext{
1 Artykuł złożono do recenzji w maju 2018.
} 
spiracji jego nauczania społecznego. W związku z tym podjęto następujące kwestie badawcze: określono rolę Kościoła katolickiego w systemie politycznym Polski; sprecyzowano metody oddziaływania Kościoła na system polityczny; zdefiniowano pojęcie prokościelnych grup interesu w tym grup pro-life; dokonano ich typologizacji; syntetycznie omówiono projekty ustaw dotyczących aborcji w Sejmie VIII kadencji; zanalizowano metody, jakimi prokościelne grupy interesów artykułowały swoje postulaty w trakcie prób stanowienia ustawodawstwa antyaborcyjnego. W celu realizacji przedmiotu badań odwołano się do metod: analizy systemowej, historycznej, instytucjonalno-prawnej. W artykule podjęto weryfikację hipotezy zakładającej, że prokościelne grupy interesu prezentują jednolite stanowisko wobec zakresu zmian ustawodawstwa antyaborcyjnego.

\section{KOŚCIÓŁ KATOLICKI A SYSTEM POLITYCZNY}

Przez pojęcie Kościół katolicki należy rozumieć przede wszystkim „Kościół hierarchiczny", nie zaś wspólnotę wiernych. Termin ten jest tożsamy z katolicką hierarchią kościelną, tj. biskupami, w szczególności diecezjalnymi. Biskupi przekazują istotne treści nauczania społecznego Kościoła (NSK). Nauczanie to jest definiowane jako doktryna społeczna, przyjmowana, interpretowana i ujednolicana przez Urząd Nauczycielski Kościoła (Magisterium Kościoła). Urząd ten tworzą papież i biskupi. NSK jest formułowane w pierwszej kolejności przez Magisterium powszechne, papieża i sobór oraz uszczegółowiane, wyjaśniane i realizowane przez poszczególnych biskupów, przy uwzględnieniu specyfiki wielorakich, różnorodnych sytuacji lokalnych [Kompendium 2005: 51]. Poszczególni biskupi współkształtują NSK przez wydawanie listów pasterskich, głoszenie homilii, udzielanie wywiadów. Na terytorium RP biskupi skupiają się w ramach Konferencji Episkopatu Polski (KEP). Organ ten wydaje dokumenty będące rozwinięciem NSK w formie listów pasterskich, komunikatów, oświadczeń oraz podejmuje dialog z władzami politycznymi.

Kościół jest definiowany w różnorodny sposób przez reprezentantów nauk o polityce, jako: wspólnota - organizacja religijna, grupa interesów, (nietypowy) aktor polityczny i religijny. W niniejszym tekście w ujęciu stricte politologicznym Kościół jest definiowany jako podmiot znajdujący się w otoczeniu systemu politycznego i oddziałujący na ten system. Podmiotowość w tym kontekście oznacza możliwość realizowania swoich celów, zamierzeń i działań, w tym sensie Kościół jest zinstytucjonalizowanym podmiotem sprawczym. Jest bowiem strukturą zorganizowaną, zhierarchizowaną. Członkowie podmiotu sprawczego przekazują część swoich atrybutów na poziom ugrupowania, w skład którego wchodzą. Ta zależność - delegacja uprawnień - wyraża się lojalnością i podporządkowaniem decyzjom podejmowanym na poziomie owego ugrupowania. Na poziomie Kościoła powszechnego kluczowe decyzje są podejmowane przez papieża w zespole Kościołów partykularnych (w danym państwie) przez Episkopat i jego prezydium, w Kościele partykularnym przez 
biskupa - rządcę diecezji. Pojęcie systemu politycznego jest określane jako ogół instytucji politycznych, za pośrednictwem których są podejmowane decyzje polityczne, oraz generalnych norm i zasad regulujących stosunki między nimi. W ujęciu instytucjonalnym pojęcie instytucji politycznych odnosi się do zorganizowanych aktorów politycznych, przede wszystkim organów państwowych i partii politycznych. W celu urzeczywistnienia wartości i artykulacji interesów Kościół wywiera zatem wpływ na partie polityczne, aby oddziaływały na proces legislacyjny i rządowy proces decyzyjny oraz bezpośrednio na poszczególne organy władzy - parlament, rząd, sądy i trybunały. Kościół wywiera również wpływ na formalne i nieformalne reguły funkcjonowania systemu politycznego, a tym samym na zachowania zbiorowych i indywidualnych aktorów politycznych.

Podmiotem oddziaływania Kościoła krajowego są organy władzy państwowej oraz partie, grupy interesów, media i społeczeństwo. Kryterium przedmiotowe pozwala na wyodrębnienie następujących kwestii problemowych, podejmowanych przez Kościoły krajowe: sfera bieżącej polityki (stanowiska wobec wyborów, referendów); preferowany model stosunków wyznaniowych (zawarty w przepisach konstytucyjnych, konkordatu, ustawach i rozporządzeniach); kwestie społeczno-ekonomiczne (dezyderaty dotyczące polityki społecznej); finansowe i majątkowe aspekty działalności Kościoła (subwencjonowanie Kościoła ze środków państwowych, podatek kościelny, kwestie własności kościelnej); funkcjonowanie Unii Europejskiej (respektowanie wartości chrześcijańskich w ustawodawstwie unijnym).

Formy oddziaływania Kościoła na system polityczny i podmioty znajdujące się w jego otoczeniu są często zbliżone do metod i technik właściwych dla lobbingu oraz wykraczają poza klasyczne rzecznictwo interesów [por. Hierlemann 2005]. Celem tego oddziaływania jest artykulacja własnych wartości i interesów oraz przekonanie decydentów politycznych do określonych rozwiązań prawnych i administracyjnych. Można wyróżnić dwie formy oddziaływania Kościoła z uwagi na kryterium sposobu artykulacji wartości i interesów: bezpośrednie i pośrednie. W pierwszym przypadku biskupi bezpośrednio oddziałują na decydentów, w drugim zaś korzystają z pośrednictwa innych podmiotów. W ramach oddziaływania bezpośredniego można wyróżnić formy ustne i pisemne. Do formy ustnej należą: oficjalne i zakulisowe rozmowy, spotkania, konferencje, sympozja z politykami. Natomiast do formy pisanej można zaliczyć: listy, oświadczenia, dezyderaty, opracowania kierowane do decydentów politycznych. Kościół instytucjonalny dąży do realizacji swoich celów i interesów za pośrednictwem następujących podmiotów: swoich wyspecjalizowanych organów, grup interesów, mass mediów, wspólnych organów kościelno-państwowych, ekspertów, naukowców, mobilizacji opinii publicznej. Szczególną formą oddziaływania Kościoła instytucjonalnego na system polityczny, wykraczającą poza klasyczne metody lobbingu, są sankcje moralne. Mobilizują i skłaniają one indywidualnych i zbiorowych aktorów politycznych do działań zgodnych z wartościami i interesami Kościoła. Sankcje moralne są reakcjami Kościoła na zachowania swoich członków w sytuacjach społecznie ważnych. Sankcje moralne mogą mieć charakter pozytywny 
- wzmacniający, są to: pochwały, wyrazy publicznego uznania czy wsparcia dla określonego aktora politycznego, np. opowiadającego się za opcją pro-life w parlamencie. Repertuar sankcji negatywnych jest zróżnicowany: od negatywnej oceny poczynań polityka, jego potępienia, przez zerwanie z nim kontaktów, po groźbę ekskomuniki [Kowalczyk 2012: 21-36; 2014: 126-141; 2014a: 15-32].

Znaczący wpływ Kościoła katolickiego na system polityczny w Polsce po 1989 roku. wynikał przede wszystkim z jego historycznej roli, struktury wyznaniowej, uregulowanego formalno-prawnie przyjaznego modelu stosunków wyznaniowych. Kościół katolicki odgrywał istotną rolę w przemianach ustrojowych Polski, wywierając wpływ na aksjologiczne fundamenty systemu politycznego, określone regulacje ustawowe, legitymizację postsolidarnościowych elit, proces wyborczy i kierunki debaty publicznej. Model przyjęty przez Kościół hierarchiczny był swoistym balansowaniem między tym, co polityczne, a tym, co metapolityczne - obecnością w życiu wspólnoty politycznej jako uczestnika procesu politycznego a nośnikiem wartości [por. Delong 2016; Sowiński 2012].

\section{GRUPY PRO-LIFE I ICH METODY DZIAŁANIA}

Jedną z form oddziaływania Kościoła na system polityczny i jego otoczenie są grupy interesu. Grupy te odwołują się do wartości wynikających z NSK i realizują z reguły interesy Kościoła katolickiego. W niniejszym artykule są określane jako prokościelne grupy interesów.

Konrad Oświecimski określa grupę interesu jako zrzeszenie jednostek bądź organizacji lub instytucję będącą podmiotem władzy publicznej, która na podstawie wewnętrznie podzielanych wartości stara się aktywnie wpływać na kształtowanie polityki publicznej, lecz nie dąży do formalnego sprawowania władzy [Oświecimski 2012: 43-44]. Termin ten jest węższy niż religijne grupy interesów czy podmioty polityczne, odwołując się do wartości. Według Caelesty Braun-Poppelaars i Marcela Hannegraaffa, pojęcie ,religijne grupy interesu” (religious interest groups) odnosi się do różnych form organizacyjnych, ich istotą jest współdziałanie z decydentami, reprezentują one zbiór norm i wartości narzuconych przez nadprzyrodzone i bezosobowe siły, których istnienie jest traktowane jako aksjomat [Braun-Poppelaars, Hannegraaff 2011: 153]. Maciej Potz zdefiniował organizacje religijne jako unikalnych aktorów politycznych opartych na wartościach (value-based political actors) [Potz 2016: 101]. W tym kontekście można stwierdzić, że prokościelne grupy interesu to zrzeszenia jednostek, organizacji lub instytucji artykułujące postulaty Kościoła. Grupy te są naturalnymi sojusznikami Kościoła w działaniach na rzecz implementacji w ustawodawstwo państwowe preferowanych przez niego norm i wartości wynikających z NSK. W tym sensie grupy te zajmują się rzecznictwem religijnym (religious advocacy), prowadzą lobbing na rzecz Kościoła katolickiego [Knutson 2015: 3585-3599]. 
Istotną kategorią w grupie prokościelnych grup interesu są w Polsce organizacje obrońców życia pro-life. Ich celem jest: wprowadzenie całkowitej ochrony życia poczętego (zaostrzenie ustawodawstwa antyaborcyjnego); pomoc matkom w ciąży i rodzinom (zwłaszcza matkom samotnym i rodzinom wielodzietnym); propagowanie naturalnych metod planowania rodziny. Grupy pro-life odznaczają się zróżnicowaniem, biorąc pod uwagę rozmaite kryteria [zob. Kowalczyk 2017: 181-188]. Pod względem organizacyjno-formalnym można wyróżnić: stowarzyszenia (np. Katolickie Stowarzyszenie Civitas Christiana), fundacje (np. Fundacja „Głos dla Życia”), federacje (np. Polska Federacja Stowarzyszeń Rodzin Katolickich), związki zawodowe (NSZZ „Solidarność”), instytucje (np. Rada Katolików Świeckich), podmioty niesformalizowane (np. Odnowa w Duchu Świętym, grupy wiernych). Przyjmując kryterium związku z Kościołem, należy wymienić dwie kategorie grup pro-life. Grupy kościelne to podmioty działające w strukturach Kościoła. Zgodnie z Kodeksem prawa kanonicznego, stowarzyszenie może przybrać nazwę „katolickie” za zgodą kompetentnej władzy kościelnej (np. Akcja Katolicka). Przez pojęcie „grupy pozakościelne" należy rozumieć podmioty działające poza strukturami Kościoła katolickiego (np. Instytut na Rzecz Kultury Prawnej Ordo Iuris). Najważniejszą z grup pro-life jest Polska Federacja Ruchów Obrony Życia (PFROŻ), która powstała w 1992 roku. W 2016 roku skupiała ona 136 podmiotów, w tym 43 stowarzyszenia, 18 fundacji, 10 instytucji, 48 ruchów i grup nieformalnych oraz 7 lokalnych porozumień dla życia [Kim jesteśmy... 2018]. Dużą aktywnością odznacza się również Fundacja Pro - prawo do życia, de facto stowarzyszenie rejestrowe, która powstała w 2005 roku. Jej członkowie organizowali wystawy pro-life, pikiety antyaborcyjne przed szpitalami, galerami handlowymi [Fundacja Pro... 2018].

W celu realizacji swojego nadrzędnego postulatu - implementacji w polskie ustawodawstwo (ustawę zasadniczą, ustawę antyaborcyjną) przepisów o całkowitej ochronie życia poczętego - grupy pro-life, podobnie jak Kościół hierarchiczny, stosują różne metody rzecznictwa interesów. Część z nich jest właściwa dla typowego lobbingu, inne zaś wykraczają poza klasyczne rzecznictwo [por. Jasiecki, Molęda -Zdziech, Kurczewska 2006]. Stosowano zatem metody lobbingu bezpośredniego i pośredniego. Lobbing bezpośredni był adresowany do konkretnych decydentów politycznych (przede wszystkim parlamentarzystów). Lobbing pośredni był oddziaływaniem na polityków przez działania skierowane na otoczenie społeczne, opinię publiczną.

Z analizy działalności obrońców życia od 1989 roku wynika, że charakterystycznymi metodami lobbingu bezpośredniego były rozmowy z przedstawicielami władz publicznych (parlamentarzystami, członkami rządu, sędziami) na temat konieczności wprowadzenia w życie przepisów antyaborcyjnych. Aktywiści pro-life nagłaśniali swoje stanowisko podczas udziału w pracach komisji parlamentarnych. W odniesieniu do metod lobbingu pośredniego stosowano najczęściej manifestacje przed Sejmem, pikiety antyaborcyjne. Przykładem akcji happeningowych, mających na celu zwiększenie świadomości społecznej w zakresie potrzeby ochrony życia ludzkiego od 
poczęcia może być rozdawanie figurek płodu (dziecka w łonie matki). Mobilizowano również opinię publiczną przez akcje pisania petycji, wysyłania listów do decydentów z prośbą o poparcie postulatów antyaborcyjnych. Od 2006 roku organizowane są w różnych miastach Marsze dla Życia, wspierane przez Radio Maryja czy NSZZ „Solidarność” [Hennig 2012: 277]. Od 1998 roku na mocy uchwały 293. Zebrania Plenarnego Episkopatu Polski obchodzony jest 25 marca w Kościele katolickim Dzień Świętości Życia. Natomiast od 2004 roku 24 marca obchodzony jest w Polsce, ustanowiony przez Sejm, Narodowy Dzień Życia. Standardową formą działalności grup pro-life jest aktywność w mediach, odwoływanie się do wypowiedzi ekspertów (lekarzy, psychologów, prawników). Organizacje tego typu odwołują się również do metod wykraczających poza klasyczny lobbing. Do zabiegów perswazyjnych należą w tym zakresie modlitwy publiczne obrońców życia. Tradycyjnie modlitwy w intencji nienarodzonych odbywają się 28 grudnia, gdy Kościół katolicki obchodzi Święto Młodzianków Męczenników (w tradycji katolickiej uroczystość upamiętnia Rzeź Niewiniątek dokonaną na rozkaz namiestnika Galilei Heroda w Betlejem). Sankcje moralne mają skłaniać do zachowań zgodnych z wartościami preferowanymi przez grupy pro-life. Mogą mieć one charakter pozytywny - pochwały pod adresem polityków i obywateli, którzy głosują za zaostrzeniem ustawodawstwa antyaborcyjnego, lub negatywny - wobec tych, którzy optują za liberalizacją ustawy o ochronie życia i płodu ludzkiego. Specyficznym przykładem sankcji negatywnej jest tytuł Heroda Roku przyznawany przez Fundację Pro - prawo do życia. Jest on dedykowany decydentowi lub instytucji, „które w sposób szczególny wyróżniały się hipokryzją i często mimo szczególnego obowiązku chronienia pokrzywdzonych i najsłabszych działały przeciwko życiu bądź prawu do życia dzieci nienarodzonych, czy to przez konkretne działania, czy też poprzez odmowę działania" [Musiał 2015]. Wybór kandydata odbywa się w formie głosowania internetowego. Tytuł Heroda Roku otrzymali: w 2015 roku - prezydent Warszawy Hanna Gronkiewicz-Waltz (za nieprzeciwdziałanie dokonywania aborcji w stołecznych szpitalach), w 2016 roku - prezes Prawa i Sprawiedliwości (PiS) Jarosław Kaczyński (za zablokowanie w Sejmie nowelizacji ustawy antyaborcyjnej - Stop aborcji), w 2017 roku - ordynator ginekologii Szpitala Bielańskiego w Warszawie Romuald Dębski (za wykonanie 115 aborcji w 2016 r.). Należy podkreślić, że PFROŻ traktuje działania Fundacji Pro - prawo do życia jako prowokacje polityczne, które „nie służą sprawie obrony życia i jako takie zasługują na zdecydowane potępienie". Federacja negatywnie odniosła się do przyznania wspomnianego tytułu J. Kaczyńskiemu [Oświadczenie... 2016]. Zestawienie metod wykorzystywanych przez grupy pro-life w Polsce zawarto w tabeli 1. 
Tabela 1. Metody wykorzystywane przez prokościelne grupy interesu podejmujące kwestię obrony życia (pro-life)

\begin{tabular}{|c|c|c|c|c|}
\hline \multicolumn{2}{|c|}{ Lobbing bezpośredni } & \multirow{2}{*}{ Lobbing pośredni } & \multirow{2}{*}{$\begin{array}{c}\text { Zabiegi } \\
\text { perswazyjne }\end{array}$} & \multirow{2}{*}{ Sankcje } \\
\hline Ustny & Pisemny & & & \\
\hline $\begin{array}{l}\text { Spotkania } \\
\text { z decydentami } \\
\text { Udział w pracach } \\
\text { komisji } \\
\text { parlamentarnych }\end{array}$ & $\begin{array}{l}\text { Oświadczenia } \\
\text { Listy } \\
\text { E-mailing }\end{array}$ & $\begin{array}{l}\text { Manifestacje, pikiety przed } \\
\text { parlamentem } \\
\text { Happeningowe akcje pro-life } \\
\text { Petycje } \\
\text { Akcja wysyłania listów do polity- } \\
\text { ków i organów władz } \\
\text { Marsze dla Życia i Rodziny } \\
\text { Dzień Świętości Życia } \\
\text { Narodowy Dzień Życia } \\
\text { Wywiady w mediach } \\
\text { Wystąpienia publiczne } \\
\text { Konferencje prasowe } \\
\text { Broszury } \\
\text { Opracowania naukowe } \\
\text { Odwoływanie się do autorytetów }\end{array}$ & $\begin{array}{l}\text { Modlitwa } \\
\text { publiczna }\end{array}$ & $\begin{array}{l}\text { Negatywne: } \\
\text { - piętnowanie } \\
\text { polityków proabor- } \\
\text { cyjnych } \\
\text { - tytuł Heroda } \\
\text { Roku (FPPdż) } \\
\text { Pozytywne: } \\
\text { - pochwała polity- } \\
\text { ków optujących za } \\
\text { ustawodawstwem } \\
\text { antyaborcyjnym }\end{array}$ \\
\hline
\end{tabular}

* FPPdż - Fundacja Pro - prawo do życia.

Źródło: Opracowanie własne.

\section{PROJEKTY NOWELIZACJI USTAWY ANTYABORCYJNEJ OD 2015 ROKU}

Problem ochrony życia ludzkiego i zapobiegania narodzinom przez usunięcie płodu, czyli aborcję, był jednym z istotnych sporów w polskiej debacie publicznej od 1989 roku. W sporze tym zarysowały się trzy stanowiska dotyczące zakresu legalizacji aborcji. Model zakazywania aborcji prawem, postulowany przez Kościół katolicki, zakładał, że embrion albo płód są traktowane jako postać żywej istoty ludzkiej, która powinna być chroniona przez prawo. Na przeciwległym biegunie znajdowali się zwolennicy modelu aborcji na żądanie kobiety ciężarnej z pewnymi ograniczeniami. Trzecie stanowisko reprezentowali optujący za modelem wskazań lub przyzwoleń aborcji, będącego próbą kompromisowego rozstrzygnięcia konfliktu interesów kobiety ciężarnej i płodu czy interesów ogólnospołecznych. Model ów aprobuje dopuszczalność przerywania ciąży pod warunkiem uzyskania wcześniejszej zgody władz, które opracowują listę wskazań medycznych, eugenicznych, prawnych i socjalnych [Tokarczyk 2010: 201-205; por. Wejbert-Wąsiewicz 2011: 75-99].

U progu III RP w Polsce obowiązywało ustawodawstwo aborcyjne z 1956 roku. Ustawa z dnia 27 kwietnia 1956 roku o warunkach dopuszczalności przerywania ciąży stanowiła, że zabiegu aborcji można dokonać w sytuacji, gdy przemawiają za tym względy lekarskie, trudne warunki życiowe kobiety lub gdy zachodzi uzasadnione podejrzenie, że ciąża powstała w wyniku przestępstwa. 7 stycznia 1993 roku Sejm przyjął ustawę o planowaniu rodziny, ochronie płodu ludzkiego i warunkach dopuszczalności przerywania ciąży. Uznając prawo każdej istoty ludzkiej do życia od poczęcia, ustawa uznawała je za wartość znajdującą się pod ochroną prawa (art. 1). 
Kluczowe znaczenie miał przepis wprowadzający zmianę do art. 149a Kodeksu karnego, stwierdzający, że osoba powodująca śmierć dziecka poczętego podlega karze pozbawienia wolności do lat dwóch. Karze nie podlegała natomiast matka dziecka poczętego. Przestępstwa nie popełniał również lekarz w publicznym zakładzie opieki zdrowotnej, w przypadku gdy: ,1) ciąża stanowiła zagrożenie dla życia lub poważne zagrożenie dla zdrowia matki [...], 2) gdy śmierć dziecka poczętego nastąpiła wskutek działań podjętych dla ratowania życia matki albo dla przeciwdziałania poważnemu uszczerbkowi na zdrowiu matki [...], 3) badania prenatalne wskazują na ciężkie i nieodwracalne uszkodzenie płodu, 4) zachodzi uzasadnione podejrzenie, potwierdzone zaświadczeniem prokuratora, że ciąża powstała w wyniku czynu zabronionego" [Ustawa 1993]. W latach 1994-2015 podejmowano bezskuteczne próby nowelizacji ustawy z 1993 r., określanej jako tzw. kompromis aborcyjny [Hennig 2012: 271-292; Kowalczyk 2012: 287-317; 2014a: 283-312].

W Sejmie VIII kadencji rozpatrywano kilka projektów dotyczących aborcji. W projekcie Fundacji Pro - prawo do życia, wspartym przez Fundację Instytut Ordo Iuris z 19 sierpnia 2016 roku pod hasłem ,Stop aborcji” zakładano zmianę przepisów ustawy z 1993 roku i Kodeksu karnego. Nowelizacja przewidywała bezwzględny zakaz aborcji i wprowadzenie jej penalizacji. Kto spowodowałby śmierć dziecka poczętego, podlegałby karze pozbawienia wolności od 3 miesięcy do 5 lat, a w przypadku działania nieumyślnego - do 3 lat. Karze pozbawienia wolności od roku do 10 lat podlegałby ten, kto przemocą wobec matki doprowadziłby do śmierci dziecka poczętego. W przypadku gdy aborcji dokonała matka, sąd mógłby zastosować wobec niej nadzwyczajne złagodzenie kary lub odstąpić od jej wymierzenia. W sytuacji gdy matka dokonała ów czyn nieumyślnie, nie podlegałaby karze [Druk 784 2016]. Projekt należy uznać za najostrzejszy w historii inicjatyw antyaborcyjnych w III RP z uwagi na: 1) objęcie zakazem aborcji ciąży będącej wynikiem ,czynu zabronionego” i z uszkodzeniami genetycznymi; 2) wprowadzenie karalności kobiety, która poddała się usunięciu ciąży. Na posiedzeniu 6 października 2016 r. Sejm odrzucił w II czytaniu projekt nowelizacji 352 głosami za, przy 58 przeciw i 18 wstrzymujących [Głosowanie nr 12: 2016].

Projekt Fundacji Pro - prawo do życia spotkał się z częściową negatywną oceną Polskiej Federacji Ruchów Obrony Życia (PFROŻ) i Forum Kobiet Polskich (FKP). Federacja opowiadała się za utrzymaniem dotychczasowej regulacji wyłączającej kobiety dokonujące aborcji spod odpowiedzialności karnej. Prezes FKP Ewa Kowalewska argumentowała, że to „kobieta jest zawsze drugą ofiarą aborcji” [Prezes... 2016]. W podobnym duchu wypowiedzieli się biskupi, którzy w komunikacie z KEP z 374. zebrania plenarnego z 5 października 2016 roku stwierdzili, ,iż nie popierają projektów zapisów prawnych, które przewidują karanie kobiet, które dopuściły się aborcji. Te kwestie Kościół rozwiązuje w sakramencie pojednania, zgodnie z przepisami Kodeksu Prawa Kanonicznego i normami etyczno-moralnymi” [Komunikat z 374: 2016].

Ostatecznie Fundacja Pro - prawo do życia wyraziła poparcie dla projektu nowelizacji ustawy PFROŻ. Zaproponowany przez federację projekt zakładał wykreślenie przepisu dopuszczającego aborcję z przyczyn eugenicznych [Druk 2146 2018]. 
17 sierpnia 2017 roku został on skierowany na ręce marszałka Sejmu Marka Kuchcińskiego, który 1 września przyjął zawiadomienie o utworzeniu Komitetu Inicjatywy Ustawodawczej „Zatrzymaj aborcję”. Grupy pro-life przystąpiły do zbierania 100 tys. podpisów. W apelu Prezydium KEP z 8 listopada 2017 roku wezwano do poparcia tej inicjatywy [Prezydium KEP 2017]. 30 listopada 2017 roku 830. tys. podpisów złożono w Sejmie. 11 stycznia 2018 roku Sejm, przy 277 głosach za, 134 przeciw i 7 wstrzymujących się, skierował projekt do dalszych prac w Komisji Polityki Społecznej i Rodziny z zaleceniem zasięgnięcia opinii Komisji Sprawiedliwości i Praw Człowieka (KSiPC) [Głosowanie nr 10 2018]. W komunikacie Prezydium KEP z 11 stycznia 2018 roku biskupi podziękowali wolontariuszom zbierającym podpisy oraz obywatelom i posłom, którzy poparli projekt [Komunikat Prezydium 2018]. 19 marca 2018 roku. KSiPC zaopiniowała pozytywnie do Komisji Polityki Społecznej i Rodziny (KPSiR) projekt ustawy „Zatrzymaj aborcję" [Skrócona ... 2018]. W komunikacie z tego dnia przewodniczący KEP abp Stanisław Gądecki podziękował KSiPC za udzielenie pozytywnej rekomendacji projektowi [Komunikat Przewodniczącego 2018]. 11 kwietnia 2018 roku KPSiR 29 głosami za, przy 3 wstrzymujących i 1 przeciw zadecydowała, iż nie włączy projektu „Zatrzymaj aborcję” do porządku obrad. Inicjatorka projektu Kaja Godek stwierdziła, że komisja ,utrzymuje w prawie zabijanie dzieci i odpowiada za śmierć 3 maluchów dziennie” [Projekt „Zatrzymaj... 2018]. Odnosząc się do głosowania w KPiSR, w komunikacie biskupi ubolewali, że głos 830 tys. obywateli nie został wystarczająco usłyszany [Komunikat 2018].

Jednocześnie grupy pro-choice występowały z projektami liberalizującymi ustawę antyaborcyjną. 24 listopada 2017 roku do Sejmu wpłynął obywatelski projekt ustawy o prawach kobiet i świadomym rodzicielstwie. W zgłoszonym przez Komitet Inicjatywy Ustawodawczej „Ratujmy Kobiety” projekcie zakładano, że kobieta ma prawo do usunięcia ciąży do 12. tygodnia [Druk 2060 2017]. Powyżej 12. tygodnia ciąża mogłaby zostać przerwana, gdyby zaistniała któraś z wymienionych w obowiązującej ustawie przesłanek; przy czym decyzję o usunięciu podejmowałaby sama kobieta. W projekcie aborcję nazwano „świadczeniem zdrowotnym” polegającym na działaniu medycznym „mającym na celu uniemożliwienie dalszego rozwoju zarodka lub płodu przy użyciu metod farmakologicznych, mechanicznych lub łączonych”. W przypadku zagrożenia życia lub zdrowia kobiety, po złożeniu przez nią pisemnej zgody na aborcję byłaby ona dokonywana w ciągu 72 godzin [Druk 2060 2017]. Projekt został poparty przez 79 organizacji lewicowych. Na posiedzeniu Sejmu 10 stycznia 2018 roku projekt odrzucono 204 głosami za, przy 197 przeciwnych i 7 wstrzymujących [Głosowanie nr 9 2018].

Natomiast 18 stycznia 2018 roku grupa posłów z partii Nowoczesna wniosła projekt Ustawy o świadomym macierzyństwie, datowany na 17 listopada 2017 roku. Zakłada on, że na żądanie kobiety będzie ona mogła usnąć ciążę do 12. tygodnia jej trwania. Przerwanie ciąży będzie możliwe jedynie wtedy, gdy kobieta po złożeniu żądania na piśmie odbędzie konsultację, której celem będzie uzyskanie informacji dotyczących skutków przerwania ciąży, a także form pomocy dla kobiet w ciąży [Ustawa 2017]. 
Można przyjąć założenie, iż w Sejmie VIII kadencji nie zostanie znowelizowana ustawa o planowaniu rodziny, ochronie płodu ludzkiego i warunkach dopuszczalności przerywania ciąży. Z uwagi na dominację prawicy światopoglądowej w parlamencie nie jest możliwa liberalizacja ustawy antyaborcyjnej. Usunięcie przez KPSiR z harmonogramu prac projektu „Zatrzymaj aborcję” świadczy o tym, że mało prawdopodobne jest również zaostrzenie obowiązującego w tym zakresie ustawodawstwa. Wprowadzenie bezwzględnego zakazu usuwania ciąży mogłoby również skutkować utratą przez PiS części umiarkowanego światopoglądowo elektoratu. Większość Polaków opowiada się za utrzymaniem ,kompromisu aborcyjnego” z 1993 roku. Z badania przeprowadzonego przez CBOS w listopadzie 2016 roku wynika, że 58\% respondentów uznało, że nie należy zmieniać istniejącego ustawodawstwa antyaborcyjnego. W elektoracie PiS zwolennicy tej opcji stanowili ponad 50\% badanych, natomiast $20 \%$ zwolenników tej partii opowiadało się za liberalizacją przepisów, a tylko 14\% za ich zaostrzeniem [CBOS 2016].

\section{METODY DZIAŁANIA GRUP PRO-LIFE OD 2015 ROKU}

W trakcie zbierania podpisów pod projektami obywatelskimi i stanowienia procesu ustawodawczego grupy pro-life podejmowały działania: na rzecz zaostrzenia ustawodawstwa antyaborcyjnego, dyskredytacji grup pro-choice. Zastosowano metody bezpośrednie, pośrednie, perswazyjne i sankcje. W tym celu obrońcy życia spotykali się z posłami, udzielali licznych wywiadów w mediach. W oświadczeniu Centrum Bioetyki Rady Naukowej Instytutu na Rzecz Kultury Prawnej Ordo Iuris z 4 grudnia 2017 roku stwierdzono, że projekt „Zatrzymaj aborcję” uświadamia, iż przepisy ustawy z dnia 7 stycznia 1993 roku „dyskryminują dzieci poczęte, u których zachodzi podejrzenie choroby lub ryzyko niepełnosprawności. Stan ten jest sprzeczny z konstytucyjnymi, międzynarodowymi i ustawowymi standardami ochrony praw dziecka" [Stanowisko... 2017]. Stałą metodą lobbingu na rzecz zaostrzenia ustawodawstwa antyaborcyjnego były marsze na rzecz życia i rodziny. Podczas zawodów o Puchar Świata w skokach narciarskich w Wiśle w listopadzie 2017 roku obrońcy życia prowadzili akcję uświadamiającą wśród kibiców, czym jest aborcja [Wśród kibiców... 2017]. Odwołano się również do zabiegów perswazyjnych w formie modlitwy publicznej. W dniu pierwszego czytania projektu „Stop aborcji” (22 września 2017 r.) z inicjatywy Krucjaty Młodych około 100 osób modliło się przed Sejmem $\mathrm{w}$ intencji przyjęcia tej nowelizacji.

W kategoriach sankcji pozytywnych należy rozpatrywać wypowiedź dyrektorki Fundacji Citizen GO Polska Magdaleny Korzekwy-Kaliszuk, odnoszącą się do deklaracji Prezydenta RP Andrzeja Dudy, który zapowiedział, że jeśli ustawa „Zatrzymaj aborcję" zostanie przegłosowana w parlamencie, to on ją podpisze. Jak stwierdziła M. Korzekwa-Kaliszuk: „Ta deklaracja ogromnie cieszy i daje nadzieję na to, że Polska przestanie dyskryminować swoich obywateli ze względu na podejrzenie ich 
chorób czy niepełnosprawności, a to obecnie $95 \%$ aborcji w polskich szpitalach" [Już ponad ... 2017]. Sankcją negatywną było przyznanie tytułu Heroda Roku przez Fundację Pro - prawo do życia wspomnianym osobom. Chcąc napiętnować polityków, Fundacja Życie i Rodzina opublikowała listę posłów z sejmowej KPSiR, którzy w głosowaniu przyczynili się do odrzucenia wniosku o włączenie do harmonogramu prac projektu ,Zatrzymaj aborcję" [Postowie... 2018].

Jednocześnie prokościelne grupy interesów dyskredytowały działalność organizacji optujących za prawem kobiety do usunięcia ciąży. Odpowiedzią na „czarne protesty” grup pro-choice (2016-2018) ${ }^{2}$ były „białe protesty”, organizowane przez obrońców życia w formie manifestacji w wielu miastach. Instytut Ordo Iuris zawiadomił prokuraturę o podaniu przez komitet „Ratujmy kobiety” fałszywych informacji na temat liczby zebranych podpisów [Ordo Iuris... 2017]. W przygotowanej analizie prawnicy Ordo Iuris zwrócili uwagę, że projekt ustawy „Ratujmy kobiety” jest sprzeczny z konstytucją, łamie prawo międzynarodowe (Konwencja o prawach dziecka, Deklaracja Praw Dziecka ONZ), łagodzi odpowiedzialność sprawców przemocy wobec kobiet w ciąży oraz prowadzi do bezkarności lekarzy winnych śmierci dziecka nienarodzonego [Projekt „Ratujmy... 2018].

\section{ZAKOŃCZENIE}

Kościół katolicki w Polsce jest podmiotem, który oddziałuje na system polityczny. Wpływa bezpośrednio na proces stanowienia prawa przez związane z nim podmioty, tj. prokościelne grupy interesów, które odwołują się do NSK. Wśród tych organizacji należy wymienić grupy pro-life, optujące za obroną życia ludzkiego od poczęcia. Polski ruch obrońców życia skupia podmioty o różnym stopniu formalizacji i powiązaniu z Kościołem hierarchicznym. Istotnym wyrazicielem środowisk pro-life jest PFROŻ. Po 1989 roku grupy pro-life podejmowały działania na rzecz wprowadzenia, następnie zaostrzenia ustawodawstwa antyaborcyjnego. W tym zakresie odwoływano się do metod typowych dla lobbingu oraz zabiegów perswazyjnych, sankcji pozytywnych i negatywnych. Egzemplifikacją powyższej tezy są działania grup pro-life podejmowane od 2015 roku. W tym kontekście zweryfikowano negatywnie hipotezę zakładającą, że prokościelne grupy interesu prezentowały jednolite stanowisko wobec zakresu zamian ustawodawstwa antyaborcyjnego. Zgłoszenie dwu różniących się projektów nowelizacji ustawy z 1993 roku stanowiło istotny wyłom w historii polskiego ruchu obrońców życia. Środowiska ,radykalne” związane z Fundacją Pro - prawo do życia, Instytutem Ordo Iuris opowiadały się za penalizacją aborcji, zaś grupy „umiarkowane”, których eksponentem była PFROŻ, były temu

\footnotetext{
2 Czarny protest był akcją wyrażającą sprzeciw wobec restrykcyjnych zmian ustawy antyaborcyjnej. Wykorzystywano trzy taktyki: strajk (polegający na nieprzychodzeniu do pracy), wyrażanie z protestującymi solidarności przez czarny strój i publiczne demonstracje [Kowalewski 2017: 64].
} 
przeciwne. Kościół hierarchiczny ostatecznie poparł projekt obywatelski „Zatrzymaj aborcję". Przebieg prac legislacyjnych w Sejmie VIII kadencji wskazuje, iż nadal zostanie utrzymany, funkcjonujący od 25 lat tzw. kompromis aborcyjny.

\section{BIBLIOGRAFIA}

Braun-Poppelaars, C., Hannegraaff, M. 2011. Conceptualizing religious advocacy: religious interest groups and the process of public policy making, [w:] Religious Actors in the Public Sphere, J. Haynes, A. Hennig (red.), Routledge, London-New York.

CBOS. 2016. Polacy o prawach kobiet, ,, czarnym proteście” i prawie aborcyjnym. Komunikat z badań $\mathrm{nr}$ 165/2016, https://www.cbos.pl/SPISKOM.POL/2016/K_165_16.PDF (dostęp: 16.04.2018).

Delong, M. 2016. Konferencja Episkopatu Polski wobec wybranych kwestii politycznych $i$ społecznych w Polsce w latach 1989-2014, Wydawnictwo Uniwersytetu Rzeszowskiego, Rzeszów.

Druk nr 784. Obywatelski projekt ustawy o zmianie ustawy z dnia 7 stycznia 1993 r. o planowaniu rodziny, ochronie płodu ludzkiego i warunkach dopuszczalności przerywania ciąży oraz ustawy z dnia 6 czerwca 1997 r. - kodeks karny, 19.08.2016, http://sejm.gov.pl/Sejm8.nsf/druk.xsp?nr=784 (dostęp: 6.04.2018).

Druk nr 2060, Warszawa 24 listopada 2017 r., http://orka.sejm.gov.pl/Druki8ka.nsf/0/AECC1FCF910247EAC12581E20042A0B4/\%24File/2060.pdf (dostęp: 14.04.2018).

Druk nr 2146. Obywatelski projekt ustawy o zmianie ustawy z 7 stycznia1993 r. o planowaniu rodziny, ochronie płodu ludzkiego i warunkach dopuszczalności przerywania ciąży, 4.01.2018, http://orka.sejm.gov. pl/Druki8ka.nsf/0/F18A213C98C5BDC0C125820B005793D9/\%24File/2146.pdf (dostęp: 8.04.2018).

Fundacja Pro - prawo do życia, https://stopaborcji.pl/ (dostęp: 4.04.2017).

Głosowanie nr 10 na 55. posiedzeniu Sejmu dnia 10-01-2017 r. o godz. 22:56:49, http://sejm.gov.pl/Sejm8. nsf/agent.xsp?symbol=glosowania \&NrKadencji $=8 \& N r P o s i e d z e n i a=55 \& N r G l o s o w a n i a=10$ (dostęp: 8.04.2018).

Głosowanie nr 12 na 27. posiedzeniu Sejmu dnia 06-10-2017 r. o godz. 11:09:49, http://sejm.gov.pl/Sejm8. nsf/agent.xsp?symbol=glosowania\&nrkadencji $=8 \&$ nrposiedzenia $=27 \& n r g l o s o w a n i a=12$ (dostęp: 6.04.2018).

Głosowanie nr 9 na 55. posiedzeniu Sejmu z dnia 10-01-2018 o godz. 22:42:49, http://sejm.gov.pl/Sejm8. nsf/agent.xsp?symbol=glosowania\&NrKadencji $=8 \& N r P o s i e d z e n i a=55 \& N r G l o s o w a n i a=9($ dostęp: 15.04.2018).

Hierlemann, D. 2006. Lobbying der katholischen Kirchen: Das Einflussentz des Klerus in Polen, Springer VS,Wiesbaden.

Hennig, A. 2012. Morapolitik und Religion. Bedingungenpolitisch-roligiöser Kooperation in Polen, Italien und Spanien, Ergon-Verlag, Würzburg.

Jasiecki, K., Molęda-Zdziech, M., Kurczewska, U. 2006. Lobbing. Sztuka skutecznego wywierania wptywu, Oficyna Ekonomiczna, Kraków.

Kim jesteśmy, http://federacjazycia.pl/pg/pl/kim jestesmy.html\&sitePage=1 (dostęp: 4.04.2018).

Knutson, K. 2015. Interfaith Advocacy Groups in American Politics, [w:] The Changing Word Religion Map. Sacred Places, Identities, Practices and Politics, S.D. Brunn (red.), Springer Netherlands, Dordecht.

Kompendium nauki społecznej Kościoła, 2005, Wydawnictwo Jedność, Kielce.

Komunikat Prezydium Konferencji Episkopatu Polski ws. procedowania europejskiej inicjatywy ustawodawczej zwiększającej ochronę prawa do życia, Warszawa, dnia 11 stycznia 2018 r., http://episkopat. $\mathrm{pl} /$ prezydium-episkopatu-dziekuje-organizatorom-wolontariuszom-sygnatariuszom-oraz-poslom-glosujacym-za-zyciem/ (dostęp: 9.04.2018).

Komunikat Przewodniczącego Konferencji Episkopatu Polski w sprawie obywatelskiego projektu „Zatrzymaj aborcje”, Warszawa, 19 marca 2018 r., http://episkopat.pl/przewodniczacy-episkopatu-dziekuje-sejmowej-komisji-za-respektowanie-praw-czlowieka-i-poparcie-projektu-zatrzymaj-aborcje-2/ (dostęp: 10.04.2018). 
Komunikat ws. ochrony prawa do życia bez względu na stan zdrowia, Warszawa 12.04.2018 r., http://episkopat.pl/komunikat-ws-ochrony-prawa-do-zycia-bez-wzgledu-na-stan-zdrowia/ (dostęp: 13.04.2018).

Komunikat z 374. Zebrania Plenarnego Konferencji Episkopatu Polski, Warszawa, dnia 5 października 2016 r., http://episkopat.pl/komunikat-z-374-zebrania-plenarnego-konferencji-episkopatu-polski/ (dostęp: 7.04.2018).

Kowalczyk, K. 2012. Partie i ugrupowania parlamentarne wobec Kościoła katolickiego w latach 19892011, ZAPOL, Szczecin.

Kowalczyk, K. 2014. Kościót jako podmiot oddziałujący na system polityczny, „Wrocławskie Studia Politologiczne", nr 17.

Kowalczyk, K. 2014a. Między antyklerykalizmem a konfesjonalizacją. Partie polityczne wobec Kościoła katolickiego w Polsce po 1989 roku, MADO, Torun.

Kowalczyk, K. 2016. Typologia grup interesu artykułujących postulaty Kościoła katolickiego w Polsce, „Przegląd Politologiczny”, nr 2.

Kowalewski, M. 2017. Czarny protest w Szczecinie, [w:] Kronika Szczecina 2016, U. Chęcińska, T. Czapiewski (red.), Wydawnictwo Zapol, Szczecin.

lk/mip. 2018. Projekt ,Zatrzymaj aborcje” poszedt w odstawkę, 12.04.2018, https://ekai.pl/projekt-zatrzymaj-aborcje-poszedl-w-odstawke/ (dostęp: 11.04.2018).

Musiał, A. 2015. Wyłoniliśmy kandydatów do tytułu Heroda Roku 2015!, https://stopaborcji.pl/wylonilismy -kandydatow-do-tytulu-heroda-roku-2015/ (dostęp: 5.04.2017).

Ordo Iuris zawiadamia prokuraturę o podawaniu przez proaborcyjny motet „, Ratujmy kobiety” fatszywych informacji na temat liczby zebranych podpisów, 6.12.2017, http://www.ordoiuris.pl/ochrona-zycia/ordo-iuris-zawiadamia-prokurature-o-podawaniu-przez-proaborcyjny-komitet-ratujmy (dostęp: 21.04.2018).

Oświadczenie PFROŻ w sprawie tytulu heroda roku, 30.12.2016, http://federacjazycia.pl/pg/pl/wiadomosci/ oswiadczenie_pfroz_w_sprawie1.html (dostęp: 5.04.2018).

Oświecimski, K. 2012. Grupy interesu i lobbing w amerykańskim systemie politycznym, Wydawnictwo WAM, Kraków.

pgo, bd, Już ponad 200 tys. podpisów pod inicjatywa „Zatrzymaj aborcję”,14.10.2017, https://ekai.pl/ zatrzymaj-aborcje-trwa-zbieranie-podpisow/ (dostęp: 20.04.2018).

Postowie zostawili dzieci bez pomocy, 13.04.2018, https://zycierodzina.pl/2018/04/13/poslowie-zostawilidzieci-bez-pomocy/ (dostęp: 21.04.2018).

Potz, M. 2016. Empowerment trough religion: religion's survival strategies in democratic politics, „Przegląd Politologiczny", nr 4. DOI: https://doi.org/10.14746/pp.2016.21.4.7.

Prezes Forum Kobiet Polskich dla KAI: jako obrońcy życia jesteśmy przeciwni karaniu kobiet, 02.10.2016, https://ekai.pl/prezes-forum-kobiet-polskich-dla-kai-jako-obroncy-zycia-jestesmy-przeciwni-karaniu -kobiet/ (dostęp: 7.04.2018).

Prezydium KEP zachęca do poparcia akcji „Zatrzymaj aborcję”, Warszawa 8.11.2017, https://ekai.pl/ prezydium-kep-zacheca-do-poparcia-akcji-zatrzymaj-aborcje/ (dostęp: 8.04.2018).

Projekt „Ratujmy kobiety” tamie konstytucję, 8.01.2018, http://www.ordoiuris.pl/ochrona-zycia/projekt-ratujmy-kobiety-lamie-konstytucje (dostęp: 22.04.2018).

rkz/mz, Wśród kibiców zbierano podpisy pod projektem „Zatrzymaj aborcję”, 20.11.2017, https://ekai. pl/wisla-wsrod-kibicow-zbierano-podpisy-pod-projektem-zatrzymaj-aborcje/ (dostęp: 18.04.2018).

Skrócona informacja o pracach komisji, 2018-03-19, http://sejm.gov.pl/Sejm8.nsf/prace_komisji_info. xsp?data=2018-03-19 (dostęp: 9.04.2018).

Sowiński, P. 2012. Boskie - cesarskie - publiczne. Debata o legitymizacji Kościoła katolickiego w Polsce w sferze publicznej, Wydawnictwo Aspra, Warszawa.

Stanowisko Centrum Bioetyki Rady Naukowej Instytutu na Recz Kultury Prawnej Ordo Iuris ws. projektu ustawy zgloszonego w ramach inicjatywy obywatelskiej ,_Zatrzymaj aborcje”, 4.12.2017, http://www. ordoiuris.pl/ochrona-zycia/stanowisko-centrum-bioetyki-rady-naukowej-instytutu-na-rzecz-kultury -prawnej-ordo (dostęp: 16.04.2018). 
Tokarczyk, R. 2010. Prawa narodzin, życia i śmierci, Wolters Kluwer Polska, Warszawa.

Ustawa z dnia 7 stycznia 1993 r. o planowaniu rodziny, ochronie płodu ludzkiego i warunkach dopuszczalności przerywania ciąży, Dz.U. 1993, nr 17, poz. 78.

Ustawa z dnia... o świadomej prokreacji. Projekt z 17.11.2017, http://orka.sejm.gov.pl/Druki8ka.nsf/ Projekty/8-020-821-2018/\$file/8-020-821-2018.pdf (dostęp: 15.04.2018).

Wejbert-Wąsiewicz, E. 2011. Aborcja między ideologia a doświadczeniem indywidualnym. Monografia zjawiska, Wydawnictwo Uniwersytetu Łódzkiego, Łódź.

THEINFLENCE OF PRO-CHURCH INTEREST GROPUS ON LEGISLATION.

CASUS OF ANTI-ABORTION REGULATION IN THE SEJM OF THE $8^{\text {TH }}$ TERM

Abstract: The main goal of the articule is to analyze the influence of pro-church interest groups on the process of anti-abortion legislation in Poland.The text refers to initiatives in the Polish parliament of $8^{\text {th }}$ term. The author analysed the following issues: the role of Catholic Church in the political system of Poland; methods of its influence on this system; the concept of pro-church interest groups and their typology; draft laws regarding abortion; methods by which pro-life groups expressed their postulates during attempts to legislate anti-abortion rules. These groups are an instrument of the Church's influence on the political system. In order to introduce anti-abortion legislation, the pro-life groups refer to various methods: lobbying, persuasion and moral sanctions.

Keywords: Catholic Church, Poland, pro-life groups

\section{BIOGRAM}

Krzysztof Kowalczyk, dr hab., prof. w Instytucie Politologii i Europeistyki Uniwersytetu Szczecińskiego. Zainteresowania badawcze: Kościół katolicki, partie polityczne, marketing polityczny, najnowsza historia Polski. Kontakt e-mail: partie2006@interia.pl. 